\title{
Biblical vistas of brokenness and wholeness in a time such as the coronavirus pandemic
}

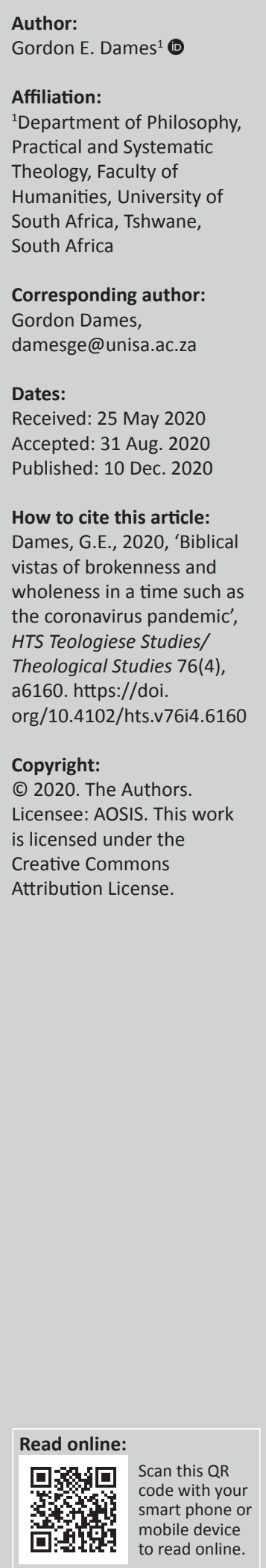

In the midst of the coronavirus (COVID-19) pandemic, new unexpected and extraordinary scenes and sounds of aesthetical biblical and apocalyptic proportions are witnessed. Community and religious gatherings in public spaces are prohibited. Modern, conventional and traditional human achievements have become futile. One can describe the COVID-19 pandemic, and this new search for meaning as a juxtaposed tension of metaphorical apocalyptic vistas and metaphorical biblical vistas. The Bible holds the same juxtaposed tension which may help humanity to rediscover the semantics of biblical truth and hope-but it also espouses a metaphorical liberational vista of transcendence. Coronavirus could be a metaphor for something with extraordinary new possibilities. The biblical metaphors are being amplified in different metaphorical vistas to make it more discerning or accessible to the world population today. As a metaphorical liberation vista, it may offer new hope for a new kind of living, a new kind of humanity, a new kind of knowing and believing and a new kind of world order.

Contribution: This article offers a Practical Theological contribution to the significance of the Bible within the COVID-19 pandemic context. Human suffering and divine metaphorical vistas encapsulate prospects for truth, hope and new meaning for the liberation of humanity.

Keywords: COVID-19; Lev Vygotsky; metaphorical vistas; aesthetics; Practical Theology; brokenness and wholeness.

\section{Introduction}

The dawn of the year 2020 characterises:

[F]ear, ignorance, deep levels of panic and uncertainty. The evacuation of South African citizens out of a major Chinese city, Wuhan - the epicentre of an acute respiratory syndrome coronavirus, brought panic and uncertainty to South Africans. (Jika \& Gilili 2020:4; Jika, Skiti \& Gilili 2020:3)

The rapid global spread of the coronavirus disease (COVID-19) does not only cause fear and panic but has claimed more than 1118635 lives, 40425663 cases of infections have been registered and counting, ${ }^{1}$ people across the globe have been infected with this silent but deadly virus (Allison 2020:5). These statistics are increasing daily. Most governments in the world have implemented stringent emergency measures such as placing whole countries on a total lockdown. The psychological effects are yet to be registered after these lockdown measures across the globe have been lifted. See the following video by 2Pac Pipe, Prince Ea, about the fear factor of the virus (2020) at https:/ / www.youtube.com/watch?v=yw1YSDmgTFI.

In the midst of this human catastrophe, new unexpected and extraordinary scenes and sounds of aesthetical biblical vistas juxtaposed with systemic barbaric gender-based killings and violence, the cultural vestiges of white supremacy fuelling deadly racism, a surge in extreme poverty levels and uncontrollable hegemonic power of apocalyptic proportions are witnessed (Bruce 2020:14; Kolwapi 2020:14; McCauley 2020:20; Saferspaces 2020; World Health Organisation 2020): For instance:

[T] he first major political shift under way before our eyes is the rebellion sweeping the US in the aftermath of the police murder of George Floyd ... [South African] police are, in fact, more violent than those in the US and kill three times more people each year. (Buccus 2020:17)

Bruce (2020:14), irrespective of his white legacy and or personal philosophical premise, raises a pertinent question: 'Why is race such a hard-wired tumour in our society and others?' His immediate response implicates Anglo-Saxon Christianity in the manner it evolved - embedded 1.These figures were captured on 20 October 2020, from the CNN Newsroom broadcaster. 
in white cultural supremacy of 800 years (Bruce 2020:14). He argues that the power of Judeo-Christianity is fading, but like a dying lethal snake, poised to inflict a deadly sting never-ending-unbearable-painful scourge on humanity (own accentuation): 'That righteous white knee on George Floyd's neck was more than 2,000 years old' (Bruce 2020:14). The ultimate outcome of the coronavirus pandemic, campaigns against gender-based violence and the Black Lives Matter movement across the world, may reshape systemic pathologies in its core and the fibre of humanity (Baccus 2020:17; Kolwapi 2020:14).

Humanity across the globe stands united in public prayer in the empty streets of major cities. Medical practitioners are praying in intensive care units in hospitals - humanity, both Christians and in some cases non-Christians, are on their knees as they solidify their call to God for protection, guidance, help, mercy and solace (Braithwaite 2020; Watch the Templo dos anjos (Oliveira 2020) at https://www.youtube.com/ watch?v=WB1zp4MzHXU). 'Religious institutions, which traditionally provide collective meaning, can no longer gather in public places, and offer communal solace' (Meylahn 2020:1). The old Italian priest and the medical doctor as well as the plea of the Italian Prime Minister signify the dichotomy of hope and despair on a scale that leaves us as humans breathless in the face of such a human tragedy (Braithwaite 2020; Urban 2020). These new scenarios of prayer and faith know no religious, denominational, or social status. Conventional and traditional boundaries have been crossed or overcame with a new kind of humanity characterised by a sense of despair and a collective display of prayer in search of the Living God's compassion. Coronavirus disease 2019 has caused a massive global tectonic shift in human life which could forever be reshaped and transformed into new meaning, new ways of being and doing and new identities. Witness the poetic aesthetics of the coronavirus for humanity in the following video by Sokol (2020) at https: / / tinyurl.com/y7q99qyz.

Modern, conventional and traditional human achievements have become futile - world leaders and medical practitioners, businesses, education, etc. are all in search of new devices to create new ways of being and doing:

Maybe Covid-19 even has the makings of a possible truth event [...] that ushers in the possibility of a new world. In that sense it can be seen to be metaphysical as it creates a new time-space, which many are concretely experiencing in their locked-down homes: a new sense of time and space. (Meylahn 2020:1)

One can describe the COVID-19 pandemic and this new search for meaningful human living as a juxtaposed tension of metaphorical apocalyptic devices and metaphorical biblical devices. The concept 'metaphorical devices' connotes to Botman's (1996) notion of metaphorical locking devices and liberating metaphorical devices. I hold that the Bible captures the same juxtaposed tension which may help humanity to rediscover the semantics of biblical truth and hope - but it also espouses a supranatural metaphorical liberational device for all of humanity. Although I adapt the concept 'metaphorical devices' for this article, I will rather refer to 'vistas'.

Let us presume that COVID-19 is a metaphor for something with extraordinary new possibilities; that the Bible can be amplified in different metaphorical vistas to make it more discerning or accessible to the world population today. As a metaphorical liberation vista, it may offer new hope for a new kind of living; a new kind of humanity; a new kind of knowing and believing; and a new kind of world order. Evidence on social media platforms illustrates a flurry of aesthetical activities. It raises the question of beauty and creativity in a context of a life-threatening pandemic. More so, how is art to be construed within the reality of COVID-19? How is it even possible that human beings could revert to creativity whilst millions are infected by this virus and hundreds of thousands across the world have died and many more are facing the inevitability of mortality?

Can it be that the famous Russian psychologist, Vygotsky (2011), may hold an answer to these complex questions? Speculation would not help our quest, but a theoretical framing of the COVID-19 pandemic within Vygotsky's (2011) aesthetical methodology may prove indispensable.

\section{Vygostksy's psychological aesthetical methodology}

According to Fróis (2011), Vygotsky is:

$[O]$ ne of the most brilliant authors of contemporary psychology at the centre of a historical time of change in twentieth-century Russia. Vygotsky problematised aesthetics and psychology of poetic and literary creation in his book Psychology of art [1925]. (pp. 107-108)

This groundbreaking work on the psychology of art explored questions in lieu of the process of art creation and the reception of the literary text. He questioned the role of emotions in art; the nature of the aesthetic experience. He illuminates the work of art as the central object of the psychology of art and emphasised the semiotic nature inherent to the fruition of works of art (Frois 2011:107). Vygotsky (2011:18) searches to clarify what makes a work of art into a true work of art. He critiques two psychological theories of art: The formalist theory of Viktor Shklovsky who saw the perception of art as an end in itself, and Tolstoy's psychological theory of art grounded on the emotional impact of art, which he contradicted. Vygotsky is against the formal qualities of objects of art and the emotional impact it has on individuals - the two approaches are unable to distinguish art from non-art. True art should hold in itself extraordinary possibilities that transcends emotions and form (Fróis 2011:108). For Vygotsky (2011:110), the only methodological possibility is to approach art with concepts that have a narrow width and a rich content. The logical opposite of this is also true. We are to discern the distinctive characteristics of art to grasp its incomparable specificity. 
Only in knowing all about that specificity can we appreciate and understand the characteristics common to art and non-art. Only knowing what art is can we determine the meaning of art; the essence of art, the salt, fire and oxygen of all existence; and the quality of an art object that defines its existence, Feuerbach and Hegel as cited, respectively, by Vygotsky (2011:110). By destroying this quality, the object of art ceases to exist (Vygotsky 2011:110). An aesthetic quality does not resonate with formalistic categories. Formalist art traits engender a different meaning with a generalised or universal category. It loses its ultimate original meaning of being and knowing(Vygotsky 2011:110).Vygotsky (2011:110) would rather speak about the specificity of form in art than of form as an end in itself. He argues against Tolstoy's emotive vocabulary or emotional effect on the subject. Such a theory assumes people as 'sentimentally infected by art and that art is rooted in this infection' - that people are the objects of art. This approach reduces art to the ordinary emotion. 'Art has no distinguishable characteristics [and its evaluation is the same as when you] evaluate any feeling' (Vygotsky 2011:113). Tolstoy's theory is thus not justifiable - its meaning and role is extremely trivial:

[I]n art we would not transcend the boundaries of the individual feeling other than in a quantitative sense ... If a poem on sadness had no other aim to infect us with sadness, this would be very sad for art. (Vygotsky 2011:115)

The true nature of art always espouses something that transcends the ordinary feeling; the same fear, pain and agitation brought about by art contain 'something' more than what they usually contain. This 'something' overcomes these feelings, and it illuminates them and illuminates the most important purpose of art (Vygotsky 2011:115). The infectious nature of art is not based on the simple transmission of feelings from one to the other. True art lifts us above the sadness; true art defeats it, overcomes it and solves it. 'How they achieve this, by what psychological [vistas] ... is the $\mathrm{X}^{\prime}$ an $\mathrm{X}$ ? $\mathrm{X}$ represents 'the proper name of art, the unknown quantity from which any investigation should start' (Vygotsky 2011:116). Vygotsky's (2011) attributes of transcendence and change or transformation are of essence for our quest and of significance in the concretisation of new meaning in our day.

Following Louw (2011:1-2), at this point, I maintain that Louw offers a good definition of practical theology insofar as it relates to Vygotsky's X theory. Louw (2011:1) refers to the intention, motivation and telos, purposeful meaning, of human actions within the field of ministry, communities of faith and social contexts. So true aesthetics should also espouse intention, motivation and purposeful meaning.

The aim of this article is not to build a broad psychological framework. It is rather to offer a narrower, in the words of Vygotsky (2011:110), conceptualised practical theological approach to aesthetics with reference to some contextual and existential challenges.

\section{Aesthetical vistas in practical theology}

I am following Vygotsky's notion of true art that transcends emotion, feelings and form and concur that true art encompasses active agency to transform any psychological or existential human condition. I will now turn to contemporary practical theologians to explore how they conceptualise art and what methods they propose. My particular interest is in the question of what the $X$ is in terms of the 21st-century practical theological perspectives. To do so, I will consult five exponents, namely, Cilliers (2013), Louw (2016), Lam (2015), Meylahn (2020) and De Villiers (2016) who have reflected on aesthetics in practical theology or theology. The following aesthetical vistas have been identified:

\section{Fragments and fullness vistas}

The tension between fragments and fullness illuminates human brokenness and wholeness. The 'in-between spaces between fragments and wholeness refer to liminality' which can be defined as being filled with potential and creativity and risk and danger (Cilliers 2013:1). It is a liminal space of uncertainty, fear and trembling for the unknown juxtaposed with the discovery of new horizons, new meaning, new circumstances and a better future. However, it is also the potential of an unchanged untransformed condition of living. Are these descriptors the new norm in a time rife of risk and danger, or are we passing yet another phase in human life?

Typical of the global lockdown is the multitude of aesthetic expressions of 'fragments' and simultaneously 'hope giving' through social media by people across the world. These expressions of fragmentation and fullness equate to laughter and weeping, worshipping God and comforting others. The 21st-century humanity finds itself in the liminal space in between the safety of individuality and the uncertain threat of communality because of the COVID-19 pandemic (Cilliers 2013:1). Furthermore, these fragments project a dissonance with notions of completely intact and fully integrated identities (Cilliers 2013:1-3). The COVID-19 pandemic has shattered the 20th-century images of a complete and perfect human race. The truth is that we are not whole or complete but are constantly-being-fragmented (Cilliers 2013:1). The incompleteness of experiences, whether from the past or the future, is a normal human experience:

Fragments from the past are those pieces of unfinished business that were never resolved, those shards of a once-intact but now destroyed whole, haunting us as torsos, as ruins, reminding us, amongst other things, of our [immortality]. The fragments of the future, on the other hand, signifies unfinished business of those experiences and endeavours of life that did not yet found their ultimate form or completion. (Cilliers 2013:2)

The same fragmentation is characteristic of faith - 'faith as not being intact, but rather to live as a fragment' (Cilliers 2013:2). On the other hand, our existential fragmented lives are synonymous with the virtues of love, peace, justice and grace or mercy - a non-rigid or non-enclaved existence. 
The concept 'grace' undergirds the notion of fragment brilliantly (cf. Figure 5). It suggests a presupposition that we are not yet whole but constantly in the processes of being created as a complete whole - 'as part of a bigger semiotic picture by God' (Cilliers 2013:2). Thus, fragmentation characterises Christian life in the liminal spaces of this world (Cilliers 2013:2).

\section{Imaginative and iconic vistas}

Borrowing from Louw (2016:1), I propose the practice of spiritual discernment over preaching. Spiritual discernment functions on a 'deeper existential and ontological level as beingwith and an orientation within life events'. It brings us into deep existential and ontological fellowship within the presence of God. Spiritual discernment happens in a place of silence. The desert fathers practised total solitude and concrete aesthetical practices as a spiritual discernment, which had transformational power (Nouwen 1981:14). It allows us to contemplate and focus on the symbols and metaphors of biblical narratives and divine and human images. Louw (2016:1) refers to the imaginative and iconic dimensions. The iconic dimension pulls us towards an aptitude of human dignity and healing (wholeness) to discover the fullness of life in concrete existential and in the Divine presence. The outcome of an iconic dimension is 'the experience of awe' (Louw 2016:1). Spiritual discernment 'is fundamentally the art of poetic seeing; an aesthetic event on an ontic and spiritual level' (Louw 2016:1; cf. Figure 1). This is how we find our language, our voice and images to discover new meaning in life. God images are a dimension of aesthetics for vistas of the 'unseen' (Louw 2016):

The iconic dimension of [spiritual discernment] is about symbols and metaphors that help people to 'see' in everyday life (a poetic gaze) the presence of God in such a way that tragic events, the awareness of death and the anguish about the fear for loss and rejection become events for signifying life and for healing (the quest for wholeness). (p. 1)

The fragments of existential life are part of our longing for wholeness or fullness in the presence of God. Iconography, thus, helps us as human beings to grasp and appropriate the aesthetics of our fragmented lives in search or longing for fullness and wholeness (Louw 2016:1).

\section{Human and divine love vistas}

For Lam $(2015: 1,3)$, the Bible book of Song and Songs is the embodiment of aesthetics of human and divine love. Thus, the biblical and experiential ontology converge in the praxis of spiritual discernment. Lam (2015:5) applies the metaphor 'vineyard' as a figurative symbol for the beloved herself and as a hermeneutical key to discern the beloved's experience of love. Spiritual discernment in lieu of Lam (2015:4-8) relates to the flow of a poem, namely, 'eros [yearning], mythos [searching], mustikos [finding], and kosmos [birthing]' (cf. Figure 2). The result is 'the beloved's transformation from a neglected vineyard (Song of Songs 1:6) to a generative vineyard (Song of Songs 8:12)'. The iconographic richness of the biblical text offers vistas of both fragments and wholeness in life (Lam 2015:1).

\section{Symbolic and imagery vistas}

Humans normally create religious, spiritual, artistic and socio-economic symbols to articulate their realty. Humanity has never before being challenged to articulate the meaning of being human as at present in the time of COVID-19. We create meaning from various symbolic resources of the past, present and future. Human beings are constantly seeking alternatives and more meaningful symbolic - imaginary systems - particularly if the current meaning system reveals cracks (Meylahn 2020:3). The creative nature of human beings is to imagine a new symbolic world, or an improved symbolic world, a new world order that is perhaps more just' (Meylahn 2020:3-4; cf. Figure 5 and Figure 6).

\section{Experiential concreteness and embody-ness vistas}

Aesthetics does not only help us to interpret biblical texts, but it guards us against narrow conceptual knowledge (De Villiers 2016:3). Aesthetics appropriates participatory knowledge as sensed, concrete and bodily-ness participation (Figure 3). ${ }^{2}$ It facilitates or mediates spiritual discernment, our experiences and self-knowledge (De Villiers 2016:4). More so, aesthetics can transform society far more effective than theology can. Fragments are vistas of the consummation of human wholeness (De Villiers 2016:5).

What I draw from the five practical theologians is the salt of Bible aesthetics. It can transform society more than theology or the church. The Bible is rich of meaningful symbolic and imaginary vistas to help us close the revealed cracks in our lives or communities. The Bible and our experience embody aesthetics of human and divine love and grace, like the flow of a prophetic poem - yearning, searching, finding and birthing God images. Vistas of the unseen creates an art of poetic seeing - aesthetic events on spiritual and ontological levels. We may, therefore, find our own voice by discovering new meaning in life. The Bible does not only articulate human and divine brokenness, but it baptises us in deeper existential and ontological experiences in the presence of God. The Bible as the 'Living Word' of God happens and recreates more profoundly in a place of silence - in solace. It invites us into the rest of God to contemplate and focus on Bible symbols, metaphors and narratives of God and human images - broken and whole. The Bible confronts and engages us between the liminal space of brokenness and wholeness. Human symbolic and narrative lived-reality and action results in transformation of life. Especially in terms of the cross of Christ through the prefiguration, configuration and refiguration of liminal spaces of brokenness re uncertainty, fear and trembling and at the same time, opens up new horizons and new

2.For more insight, see the following video: "Jesus light of the world" at Wilderness Christian Fellowship's Sunday morning servicehttps://youtu.be/HaOlbV7PGM4 (Noble 2020a). 

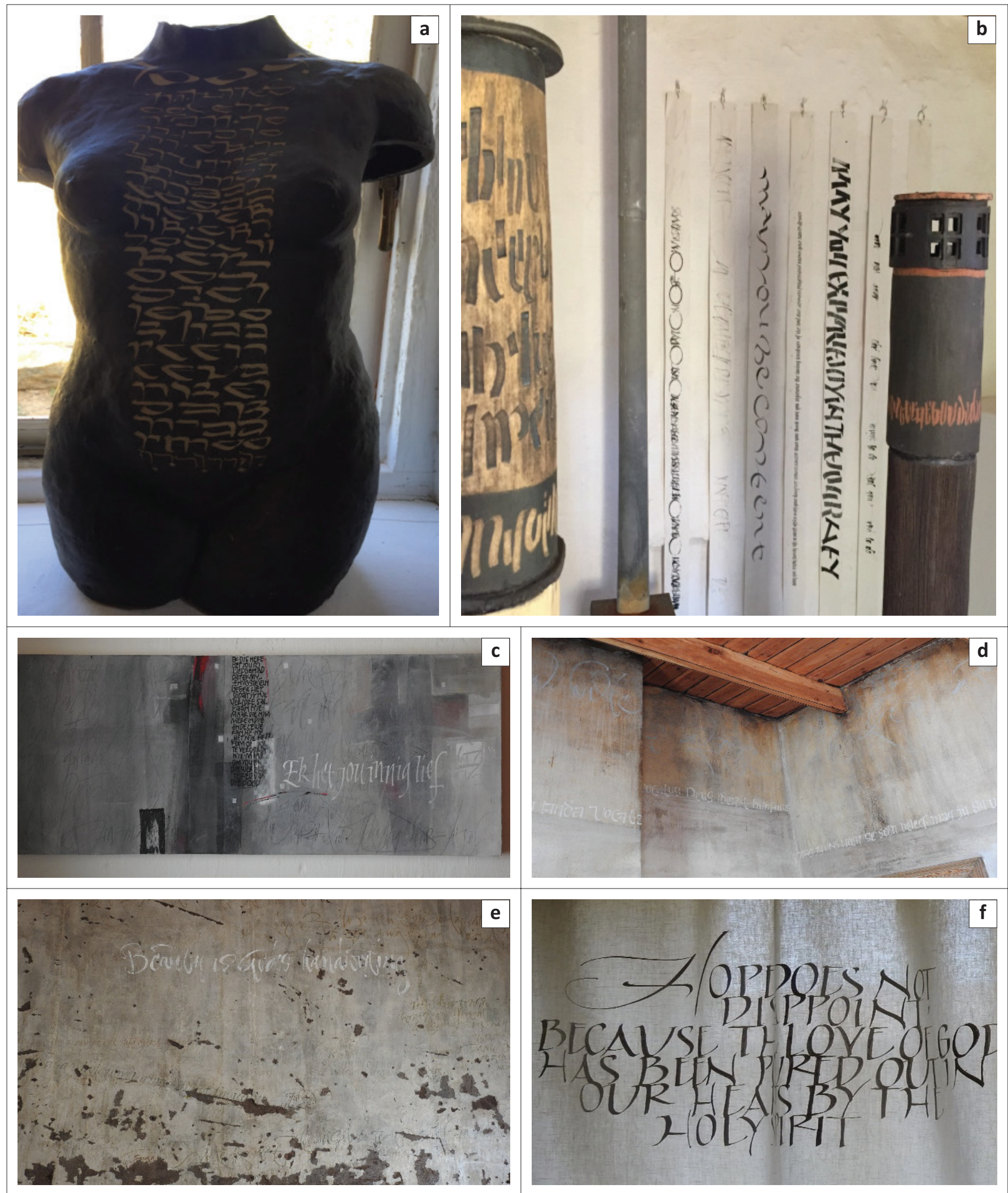

Source: Photos taken by author

(a) Torso: Divinely inspired recreation of fragmented beings; (b) Loving kindness of the Lord - faith, joy, fulfillment; (c) I love you deeply; (d) The Word as Living Movements; (e) Beauty is God's handwriting; (f) Hope does not disappoint.

FIGURE 1: Calligraphic art by Heleen de Haas used with her permission.

meaning in and through the suffering and resurrected Christ (Cf. Ricoeur 1991:22-33). Creation is the ultimate triumph of God's grace. The triumph of God's grace renders sin an ontological impossibility and brought us the vista of the bigger semiotic picture of God's reconciliation and love. 


\section{Personal engagement with local aesthetical metaphorical vistas}

The application and appropriation of the following case studies may help to illuminate the semantic value of biblical aesthetical metaphorical vistas in terms of its hermeneutical and transformational value for human beings. I selected four examples of local artists who made a meaningful impression on my senses and habitus. Note these case studies play a formative and visionary role in the lives of people and serve as a compass during challenging times. It may provide new language or a hermeneutical lens of liberation for those who suffer racism, gender-based violence and the coronavirus pandemic. Following Vygotsky (2011:110), the appropriation of the different artefacts below resonates with the aforementioned penultimate narrow width concepts with its ultimate rich existential content. These artefacts present distinctive characteristics with incomparable specificity. I will indicate the specificity of each form of art and its distinctive characteristics below in order to determine its essence. The first case study is about a local minister, colleague and family friend, Martin Bosch. The second case study is about calligraphic art by the well-known artist, Heleen de Haas. The third case study consists of both prophetic art and virtual or living art by my daughter, her friend and a wellknown local artist, Anthony Noble, respectively. These case studies will be presented to illustrate how the beauty of the Bible can break barriers and cross boundaries, but more importantly why and how it can create new meaning in life and even resurrect things or people who have died a second death or the death of the soul (my own interpretation).

\section{Case study 1: The carpenter of Wellington}

Case study 1 regarding Martin Bosch holds interesting parallels with Jesus, the carpenter of Nazareth (Matt 4):13. Bosch was born on 29 June 1940, in Graaff-Reinet and inaugurated as the minister in the Dutch Reformed Mission Church in Knysna - a coastal town in the Southern Cape in 1968. Here he and a few members of the congregation built a church that was officially opened on 30 November 1974 by himself, his wife, Myra Bosch, and as guests the congregation and the then mayoral couple of Knysna (Figure 8). The cornerstone bears the biblical text of Genesis 28:22: This stone that I erected as stone of remembrance, will be a house of the Lord. He discovered his love and sense for art in Knysna, which became a permanent hobby that he enjoyed during retirement in the warm, friendly Wellington community in the Boland in the Western Cape until his death on 28 May 2011 (Loff 1993). He also designed the building plans for the church building, in the form of a lemon press, with the help of a local artist. Chris Veltman availed his factory for the making of the woodwork for the church. It is here that the artistic Bosch developed as a distinctive and very precise carpenter in building doors, windows and benches for the project. This artistic ability and his love for woodwork grew over the years and became more than a hobby in Wellington, where he spent his retirement years (Loff 1993:9). His artistic aptitude and skill became the embodiment of his Christian faith and love for the Bible and the work of Karl Barth. The embodiment of his faith in Jesus Christ and how Karl Barth deliberated on it was part and parcel of his daily carpentry activity. Visitors were warned that if they visit whilst he is working, they would have to join him in his woodwork workshop. It is then that one became part of the Christian message of Jesus Christ's love, life, suffering, death and resurrection in soft, plain simple conversations led by Bosch. His views on Karl Barth's theology, especially in lieu of the Bible, formed a distinctive element of these conversations that lasted until late in the evenings. Many close friends bought his rich variety of solid indigenous furniture - with stringent instructions of how to take care of it. His aesthetical and carefully crafted furniture would create in its own capacity many meaningful moments of family gatherings, characteristic of participatory, reconciling and healing conversations - with the smell of wood and glue (Figure 4). His artistic legacy has truly transcended ordinary carpentry art into changed and hope-giving vistas. In the unintentional recreation of time and space where sadness, despair and pain can be confronted, overcome and transformed. Martin Bosch's artwork still exists to this day although he has passed through the valley of death. The characteristics of his artwork may be conceived in a narrow theoretical sense as ordinary daily objects. However, the specificity of his art forms transcend existential emotions of pain, despair and suffering - in the daily recreation of a gathering community in and around, within and beyond family, friends or a stranger's circle as a sign and instrument of hope and a safe space, be it the church building, a clock with kairos implications, a round table with chairs where God images are shaped and reshaped.

\section{Case study 2: The calligrapher of Aswater}

Heleen de Haas is a renowned creative calligrapher in the Western Cape in South Africa and abroad (Figure 1). Calligraphy is synonymous with the art of beautiful writing or lettering and writing design. ${ }^{3}$ What I want to illuminate is her creative art writing of spiritual and faith calligraphy. My wife and I recently went for a sabbatical of 3 days on her family farm, Aswater, between the beautiful Swartberg mountains in the Southern Cape near the small Karoo town of Prince Albert. We stayed in one of the houses on the farm known as Die Letterhuis [The Letter House]. Her creative Bible-versed calligraphy welcomes visitors in the space of the entire house - on the walls, curtains, furniture and a few wooden art artefacts. This is not just normal forms or beautifying habituated and domesticated art. The effect thereof affects your senses, perception, logical rationale and ultimately one's being and doing. It brings you in the presence of silence and solace - into the presence of God. Maybe I fashioned my own desert where I could withdraw to and 'shake off my compulsions, and dwell in the gentle healing presence of our Lord' (Nouwen 1981:30). Aesthetic artefacts fill the farmland and confronts you with impressions of, for instance, the Via Dolorosa - the cross, blood, reconciliation, the grave and resurrection of Christ.

3.Read more about the significance of her work on the website https://sites.google. $\mathrm{com} /$ site/capefriendsofcalligraphy/home/4d-march-workshop-uncial. 
It confronts you with expressions of pain, suffering and the anguish of the crucified Christ. Transcending such sadness are the many other art expressions of God's love, forgiveness, grace and salvation for sinners on the farm. These aesthetical vistas do not just impose itself onto your senses, but it invites you to enter, in my own experience, into Christ's rest (Heb 4:1-11). Until that moment, my life was not just fractured and filled with consistent and multiple formal and form-based academic and research activities but fragmented by abstract and formalistic concepts, theories and praxes of tertiary work, so as to flee, by entering a place of solace and prayer to stop the world from configuring me in its image and ways (Nouwen 1981:15). The transcendental power of these aesthetic vistas, in lieu of the Vygotskian paradigm, lifted me above the abstract and formal tertiary devices in helping me to defeat its domestication by overcoming it and by destroying its toxic impact on my life in search of wholeness and fullness - as God intended my life to be.

\section{Case study 3: Poetic and prophetic artists}

This case study consists of two aesthetic models, namely, virtual or living art and youthful prophetic art. Prophetic artists in lieu of Joel 2 receive visions of familiar people's friends or relations who may be struggling in life. These visions become God-inspired paintings or poems as a form of feedback to those who are inflicted. These aesthetical vistas flow - it is God inspired - as it is being written or painted, it unfolds or reveals itself, something the artist has no control over. A poetic flow becomes a word of knowledge for the afflicted person as a personal message from God. It also becomes a word of wisdom - God's revelation of the happenstances in the lives of other people. These artists have a gift of the Spirit just as Bezalel in Exodus 35.

My daughter used to write poetic and biblical phrases on the walls of her student residence and later her bedroom at home. For her parents, it was unacceptable and inconsiderate. We were not brought up to paint or write on the walls of our parents or our own homes! Our traditional domesticated sophistication could not find rest with this improper aesthetic vista - despite the fact that the written phrases captured the essence of biblical prophetic meaning and expression of faith-filled passion, love and hope for life. It is only when we entered Heleen de Haas' aesthetic farmland of faith-centred rest that we could reconcile, after many years, with this prophetic aesthetical aptitude present in our daily lives. It is not easy to co-exist with artists - they may seem to be unorthodox, erratic and, at the same time, the most intrigued beings. If reconciled with the ways and devices of an artist, one becomes spoilt with the richness, freshness and beauty with which they can create meaning and new hope in life. The three figures below speak of the way how she and her friend, Hoek (2020), portrays life, new life from the heart of God's creation. The characteristics in Figures 2, 5 and 6 illustrate the beauty of God's creative movement grounded in the genesis of life. Figure 2 portrays the dawning of the Kingdom of God through Jesus Christ's incarnation by the power of the Holy Spirit; and his salvific work through his suffering, death and resurrection - conquering darkness and effecting healing. It illustrates new life through the power of the Holy Spirit. Figure 5 denotes a new holy interracial or rather new-racial generation in contrast with the current existential realities and experiences of violent scenes of racism. Could the image in Figure 5 point to the non-racial image within the Trinity, God the Father, the Son and the Holy Spirit? - a missional call to racially dominated supremist and oppressed and subjugated humanity! Figure 6 connotes God's preferred future of 'no more weeping widows' and the ultimate end of discrimination against women and gender-based violence in both relational and systemic scenarios. The specificity of these artefacts points to God's transcending power over immanent anthropological conditions in and through its divine action to recreate and complete His intended creation. Figure 7 captures God's preferred future for us beautifully in terms of Jeremiah 29:11: 'For I know the plans I have for you, plans to prosper you, to give you hope and a future ...'. It is the mission of Christian communities to enact God's promise in the face of hegemonic political power, gender-based violence, racism or coronavirus pandemic conditions. All the artefacts above point us to a better future - a living hope articulated in the Bible, embodied in and through the suffering, resurrected and sovereign Christ our Lord and Saviour to be enacted by earthly visionaries.

The name Anthony Noble warrants no introduction, because it has become enshrined in the minds, experiences, lives and psyche of so many people in the country. His love and passion for the well-being of society makes him not just a role model of distinction but an instrument in God's hand to yield awareness, discernment and an ongoing search for new meaning in and through aesthetical vistas. 'I am the clay; I am the brush, it is God who paints through me', is his living witness motto. His artwork includes pottery and painting in various mediums. Young and old are usually intrigued by his skilful artistic aptitude to create new meaning in real time and space, with living art unfolding in full glare of his

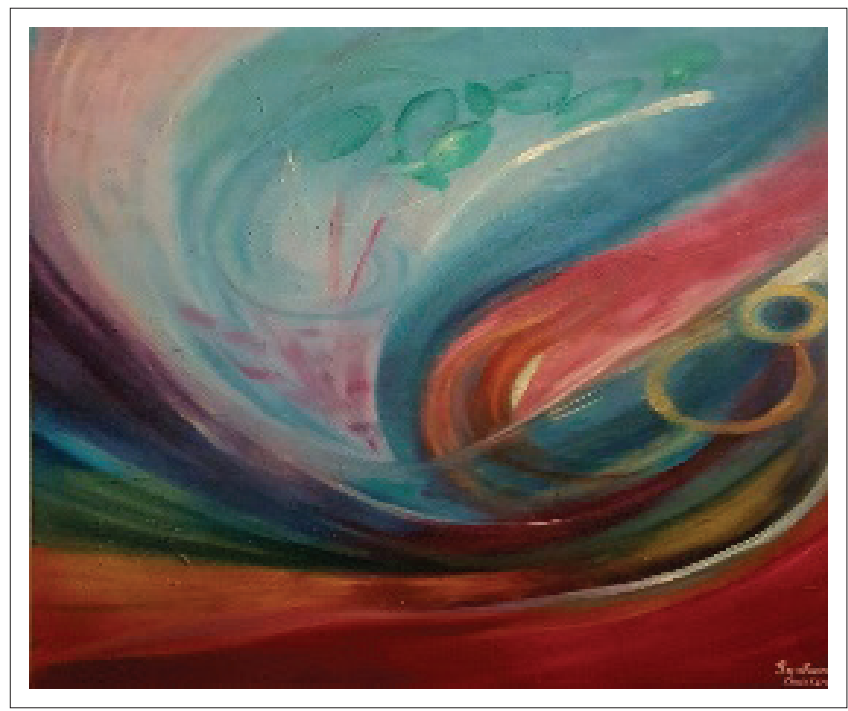

Source: Dames, C., 2015, 'Glory', Photo recording of the original painting, February 2, 2017, Wilderness, George FIGURE 2: Glory. 

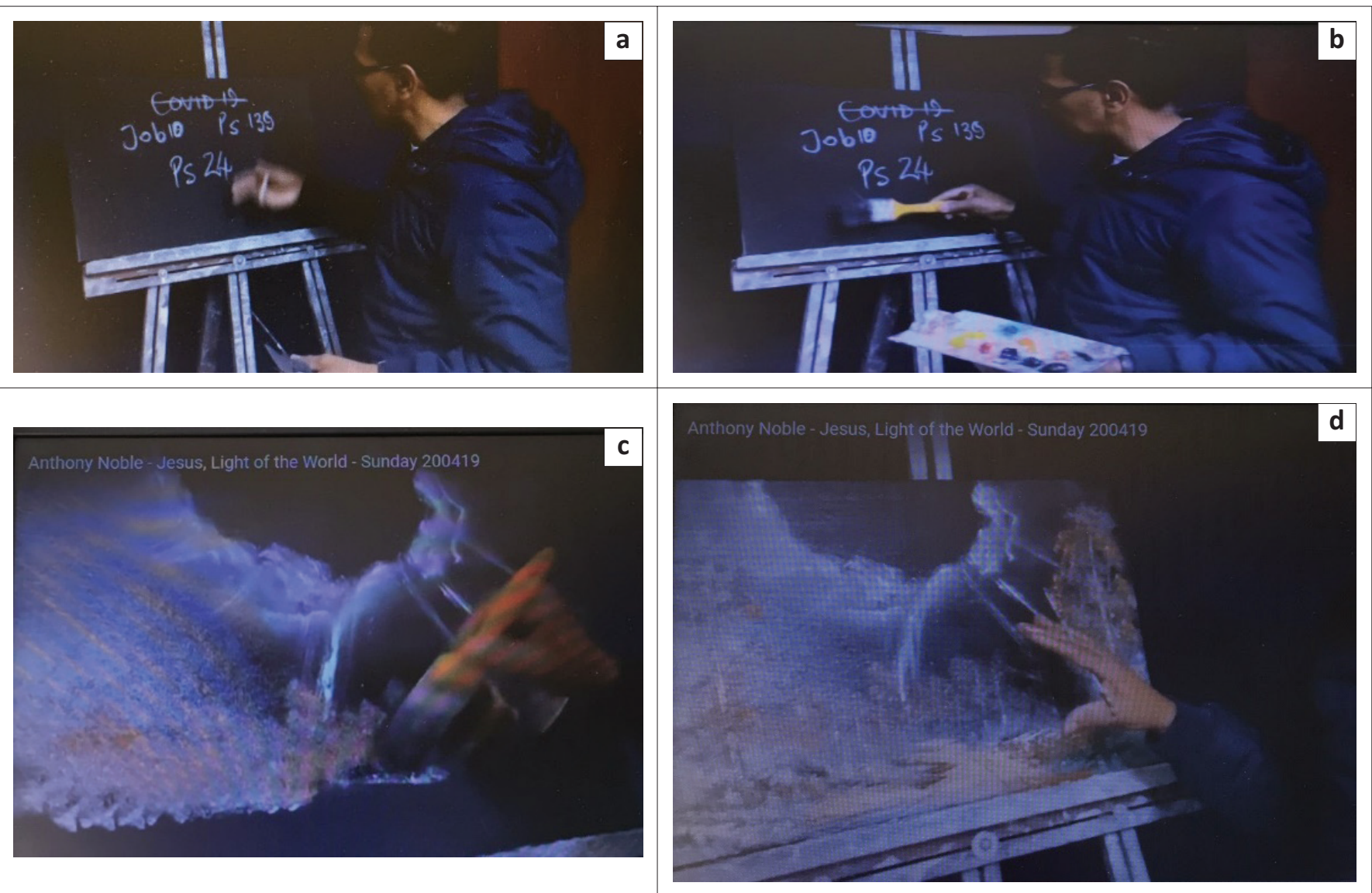

Source: Noble, A., 2020a, 'Jesus light of the world. Wilderness Christian Fellowship's Sunday morning', viewed 19 April 2020, from service https://youtu.be/HaOlbV7PGM4 (a) I am in a dark place; (b) God's word cannot be bound by COVID-19, lock down, suffering, pain or death; (c) Light flows through dark clouds; (d) Wherever Light falls roads become brighter; Christ become you companion.

FIGURE 3: Jesus, Light of the world by Anthony Noble (2020a).

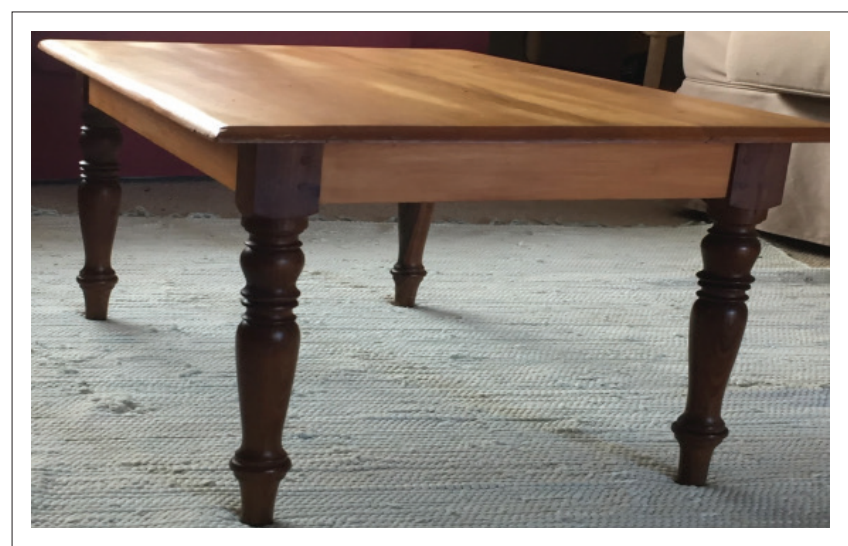

Source: Photos taken by author

FIGURE 4: Creative woodwork (own photo).

audiences. Noble does not only enact public educational art presentations as an end in itself (Noble 2018), he is constantly projecting faith-filled imagery and symbols as a proclamation of biblical truths within particular contextual realities, especially for those particular audiences who encounter existential or ontological challenges (Noble 2020a). His artistic skill and the quality of his artwork can be ascribed to the inspiration of the Holy Spirit and his faith in the crucified Christ who died and rose as conqueror over strife, pandemics and death. This is true of all the above-mentioned artists.

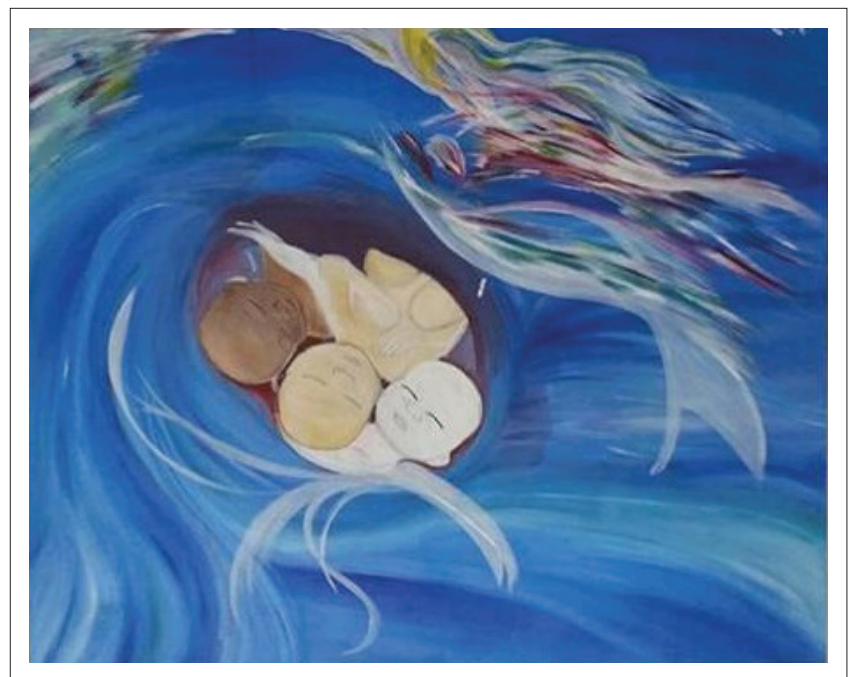

Source: Dames, C., 2019, 'Holy generation', Photo recording of the original painting, March 12, 2020, Heather Park, George

FIGURE 5: Holy generation.

It would seem that their main purpose in life is centred on the Nazarene, Jesus Christ, our Lord and Saviour. The $\mathrm{X}$ factor in his art work is his ability and skill to create four oil paintings within $1 \mathrm{~h}$ in front of his audience. This is achieved whilst he engages with his audience by confronting their sense of 'awe', unbelief and, mostly, their expressions of appreciation 


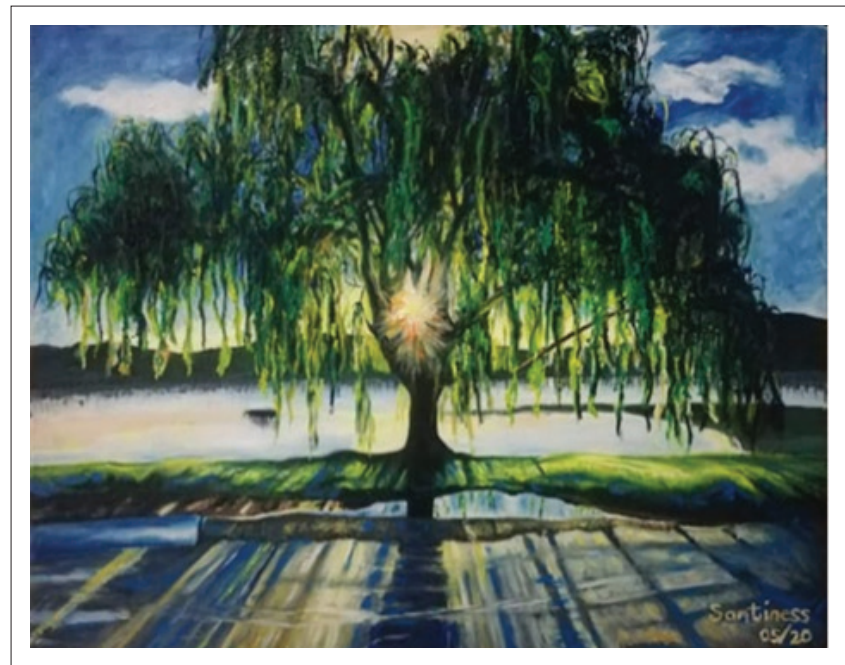

Source: Hoek, S., 2020, No more weeping widow, viewed 19 May 2020, from https:// www.facebook.com/101181758062219/posts/163386905175037/

FIGURE 6: Santie Hoek (2020) used with her permission.

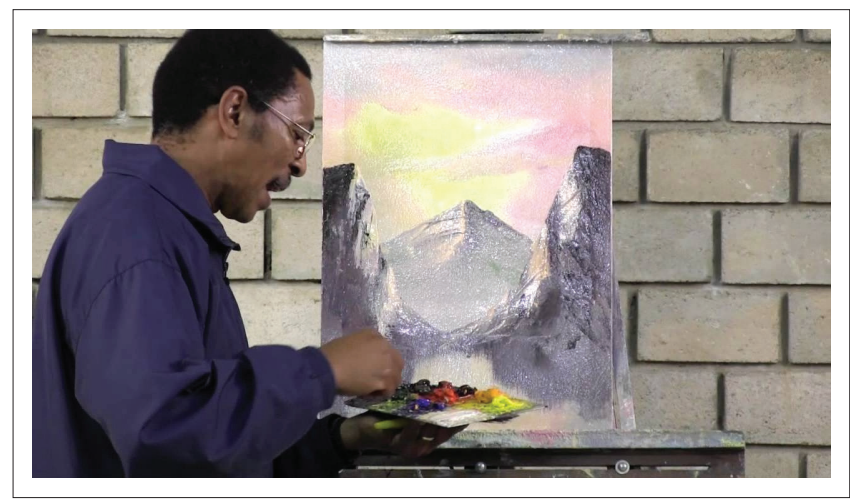

Source: Noble, A., 2012, 'God's word in art: For I know the plans I have for you, plans to prosper you, to give you hope and a future...', With ENN, endtimesnetwork.com, viewed 18 May 2020, from https://tinyurl.com/y8h66jlj 15/5/2020

FIGURE 7: Anthony Noble (2012).

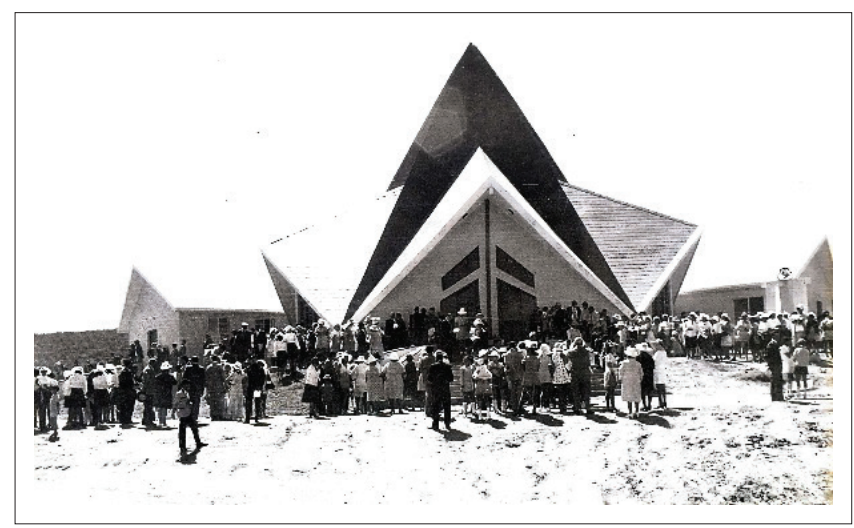

Source: Loff, C., 1993, 'Kol Bosch sluit finaal sy deur', Die Ligdraer, 13 September 13, p. 9 FIGURE 8: Knysna church building (Loff 1993).

for being able to participate in being part of a living art expedition (Noble 2020b). His passion for the Bible and its core message forms an integral part of most of his living art expeditions (Noble 2012).

These case studies prompt the question: How does art infuse meaning in life? And what type of meaning can offer us semantic value that changes our way of living or how we perceive life in a global society threatened by the coronavirus and all its socio-economic implications? We may concur that people in general know, experience and perceive life differently. The ultimate question remains, what are the specifics of these forms of art and how does it transcend existential and ontological pandemic realities? As a Christian practical theologian, my quest for answers lies, foremost, in my dwelling in the Word of God. We are wrapped by the World of God in times of fear, uncertainty, despair and hopelessness wrapped in and through the Word of God to transcend the happenstances of our ontological realities (Bostic 2020a, 2020b; Louw 2005). The lyrics in one of Bostic's (2020b) latest gospel songs, Wrapped, helped her to cope with her fear as restrictive travel measures for the COVID-19 pandemic became imminent whilst touring the United Kingdom. Her song, Wrapped, is not just an aesthetic marvel but in the words of Vygotsky (2011:115): The true nature of art transcends ordinary feelings, fear, pain, and agitation. Art contains 'something' more than what they usually contain. It overcomes feelings of depression, angts - it illuminates them and offers the most important purpose of art. True art lifts us above the sadness; true art defeats it, overcomes it, solves it, it transcends, change or transform our existential, spiritual realities and soul.

The Swiss/German theologian, Karl Barth, for me, offers the most convincing answer as well as the most aesthetical hermeneutical artistry of the Bible. His theology draws a divine aesthetic vista that offers a wide panorama of God's triumph of grace, reconciliation and salvation.

In view of all the above, Vygotsky's theory of a narrow conceptual departure with diverse specificity, as illustrated by the practical theologians above, brings us now to his theory of the width of rich content, in this case, the Bible and vice versa.

\section{Biblical aesthetical vistas}

Given Barth's love for music, especially Mozart, the following depiction of Barth's theology by William Stacy Johnson (in Bosman 2019) really seems appropriate:

\begin{abstract}
Like the music of Wolfgang Amadeus Mozart whom he so much admired, Barth's theology is a composition in which melody and reverberant countermelody run in ceaseless competition ... Like the music of Mozart, theology is in ceaseless interplay between the 'no' and the 'yes,' between a God who is made known in Jesus Christ but remains profoundly unknown in the impenetrable depths of mystery. (p. 251)
\end{abstract}

The revelation and divine mystery of God in and through Christ are the core aesthetics of the Bible.

Brueggemann (1997), for instance, sketches Luther's passion for the evangelical substance of biblical faith free of being captured in the 'habituated, accustomed, and reductionist 
reading of church theology - free from being enclaved as a church-administered system of salvation. The interpretivehermeneutical pivot point is the Bible. 'It is a voice of revelation not to be contaminated by any human categories of interpretation that [makes] the voice more coherent, domesticated, or palatable'. The liberating reality of revelation is a peculiar faith-generating and faith-driven affirmation (Brueggemann 1997:2). The voice of the Bible yields its own truth, whilst making claims of its own odd and unaccommodating categories. 'The substance of that truth is God, the Creator of heaven and earth, the God known decisively and uniquely in Jesus of Nazareth' (Brueggemann 1997:3). It is only the Bible that bears true and primary witness to the revelation of God. We are not to read 'away from the Bible', rather 'from the Bible' by dwelling in the word, ${ }^{4}$ and into its evangelical claim in terms of every fibre of personal or public life (Calvin 1960 in Brueggemann 1997:3). We are to develop as instruments in God's hand of creative interpretive emancipation (Brueggemann 1997:4).

From the above, I maintain that the Bible holds a peculiar transcendence. The Bible cannot be captured, entangled or bound by human doing.

We are always in search of wholeness and meaning therefore, our need for the aesthetics of being interpreters of the biblical truth (Smit 2013 in Bosman 2019:246). The biblical text becomes the divinely textual aesthetical vista within which God, in and through Christ and the Spirit, is active and presents to the reader, perceiver or hearer (Wallace 1996 in Bosman 2019:251). The core of the biblical text is Christ (according to Barth) whereas the world of the text (cf. Ricoeur) entails a vast collective of imaginative human possibilities (in Bosman 2019:251). Note Vygotsky's notion of a narrow concept and the width of content with its specificity in the aforementioned argument. Hermeneutics of the Bible veils or hides God in metaphors or symbols to reveal himself (McCormack 1997 in Bosman 2019:252). The Word of God engages us in a triad event; namely, the act of revelation, the enhuminisation of God's own Word as the man or carpenter of Jesus of Nazareth and prophetic and apostolic words (cf. Loff 1993; Dames 2015; 2019; De Haas 2020; Hoek 2020; cf. Figures 4 and 8). The witnessing of the Word of God by its bearers and witnesses - human speech and acts, becomes word of God - divine speech-act (Hart 1999; Webster 2000 in Bosman 2019:252-253). The Bible opens up a new world, an aesthetical triumph of the Word of God: 'Something wholly different - a new beginning with its own [distinctiveness]' (Barth 1928 in Bosman 2019:253-254). This something new is the aesthetical attribute of sin - an ontological impossibility because of the salvific metaphorical vistas of the cross, God's grace, his reconciliatory work and his re-creation. This is the pivotal point - the aesthetics of the Bible.

4The scriptural discernment ' $m$ ethod' Dwelling in the Word, is instrumental in the journey of spitual discernment. Dwelling in the Word forms and reforms all the jour ey spiritual discernment. Dwelling in the Word forms and reforms all practices of spiritual discernment. This methodology facilitates certain outcomes, namely, the transformation of people's attitudes and beliefs, knowledge, skills, habits and practices (Keifert 2006:64, 70-71).
Sin, however, is fixated with fragmentation, domination, domestication and static form. Sin is a horrible reality, but it cannot break through the limit set by the boundary of grace:

Only in a context of grace can we face our sin; only in the place of healing do we dare to show our wounds; only with a single-minded attention to Christ can we give up our clinging fears and face our own true nature. (Nouwen 1981:30)

In creation, light and darkness are separated. Sin is ontologically impossible.

Hence, the prefiguration of the triumph in creation is fulfilled and confirmed in the history of Christ as the triumph of reconciliation (Berkouwer 1956:123). In and through Christ, we must learn who God is and what the really divine is and can do (Berkouwer 1956:126). Reconciliation engenders liberating metaphorical vistas (Botman 1996:41). 'For Luther, the cross of Christ represents fragmentation per excellence ... in this sense the "ugliness of God" becomes an aesthetic category in a Christian spiritual approach to iconography' (Cilliers 2013:2; original emphasis; Louw 2016:1). How can this 'divine ugliness' be aesthetical and iconic at the same time?

In the resurrection of Christ as the exclusive act of God's grace, our whole situation and that of the entire world has been changed. The new situation exists independently of the proclamation or non-proclamation of it. It also exists independently of belief or non-belief in it. The Kingdom of God 'has its truth in itself, not in that which in pursuance of it happens or does not happen on the earth' (Berkouwer 1956:138). Therefore, the Bible is in the world to witness to this changed situation which affects all and is reality for all (Berkouwer 1956:139-140). God has been recreating the world since His son, Jesus Christ, walked the earth, suffered, died and resurrected from death - in and through all the symbols, signs and metaphors of the Kingdom of God, He shared with His followers. The Bible is a living witness of the signs of the Kingdom of God (Ridderbos 1962) - God's preferred future for the recreation of His living church (Guder 2000). Compare and experience the aesthetical vistas in the following video, If this time, by McCormack (2020) at https://www.youtube.com/ watch?v=FINeXA-fRZE.

\section{Conclusion}

The aesthetics of crisis engendered by COVID-19 brought the Bible full blow and in plain public sight to the marketplace where it was all along supposed to feature, live and act - not in habituated, dominated or domesticated liturgies captured between church walls on a Sunday or denominations, but outside of the walls of the Temple in Jerusalem, outside the city, on an ash heap, where waist is gathered, where you will find the cross of the living Christ (Jn 19:17ff.; Lk 23:33). The above illustrated case studies are creative images and symbols of biblical vistas of God transcending boundaries. Coronavirus 
disease 2019 has 'open-the-eyes-and-ears' of the domesticated church to transcend dogma, conventional, traditional, denominational, religious and social or class boundaries.

Outside the walls of Jerusalem - on the edge of civilisation and the fringes of human life, we may see metaphorical biblical vistas like the living water for the women at the well in Samaria (John 4) or the aesthetic expression of the painting, no more weeping widows (Figure 5). The famous musical song composed and performed by Paul Simon and Art Garfunkel in Central Park, New York, in the United States of America during the 70s:

People talking without speaking; people hearing without listening. People writing songs that voices never share and no one dared; disturbed the sound of silence; ... my words like silent rain drops fell and echoed in the wells of silence and the people bowed and pray to the neon god they made; And the sign flashed out its warning; in the words that it was forming; and the sign said: 'The words of the prophets are written on the subway walls and tenement halls'; whispered in the sounds of silence. (Simon \& Garfunkel 2009)

This song captures the essence of all the above - an opportune time for the Bible to breath at last outside of confessional, dogmatic and denominational walls forming words of life on the subway walls and in the dwelling places where millions of destitute and poor people live.

\section{Acknowledgements}

This work is based on the research supported in part by the National Research Foundation of South Africa (Grant Number 109389).

Heleen de Haas - Art work - used with her permission. Santie Hoek - Art work - used with her permission. Caitlin Dames art work - used with her permission.

\section{Competing interests}

The author has declared that no competing interest exists.

\section{Author's contributions}

I declare that I am the sole author of this research article.

\section{Ethical consideration}

This article followed all ethical standards for a research without direct contact with human or animal subjects.

\section{Funding information}

National Research Foundation (Grant number 109389).

\section{Data availability statement}

Data sharing is not applicable to this article as no new data were created or analysed in this study.

\section{Disclaimer}

The views and opinions expressed in this article are those of the authors and do not necessarily reflect the official policy or position of any affiliated agency of the author.

\section{References}

Allison, S., 2020, 'How the coronavirus has spread: Virus spread globally - but don't panic yet', Mail \& Guardian, 28 February to 5 March 2020, p. 5 .

Berkouwer, G.C., 1956, The triumph of grace in the theology of Karl Barth, Paternoster, London.

Bostic, J., 2020a, 'Wrapped', viewed 29 June 2020 from https://www.youtube.com/ watch?v=1awPCWuSqE4.

Bostic, J., 2020b, 'Wrapped (Behind the song): As travel bans became imminent, Christian artist Jenn Bostic is deep into a tour in the United Kingdom', viewed 29 June 2020 from https://www.youtube.com/watch?v=pvmFyrmVCag.

Bosman, H.L., 2019, 'Karl Barth's interpretation of Scripture from the perspective of a possible "second naivety", Stellenbosch Theological Journal 5(3), 245-263. https://doi.org/10.17570/stj.2019.v5n3.a12

Botman, H.R., 1996, 'Narrative challenges in a situation of transition', in H.R. Botman \& R.M. Petersen (eds.), To remember and to heal: Theological and psychological reflections on truth and reconciliation, pp. 37-46, Human \& Rousseau, Cape Town.

Braithwaite, S., 2020, 'Sixty-one Italian doctors have died during coronavirus crisis', viewed 30 March 2020, from 7:57 am ET., https://www.faithpot.com.

Brueggemann, W., 1997, Theology of the Old Testament: Testimony, dispute, advocacy, Fortress Press, Minneapolis, MN.

Buccus, I., 2020, 'As the life and death of George Floyd matter, so do Collins Khosa's: Outrage in the US at police violence could shape politics in South Africa', Sunday Times, 07 June, p. 17

Bruce, P., 2020, 'Ancient culture of domination spawns another murder', Sunday Times, 07 June, p. 14

Cilliers, J., 2013, 'Between fragments and fullness: Worshipping in the in-between spaces of Africa', HTS Teologiese Studies/Theological Studies 69(2), Art. \#1296, 6 pages. https://doi.org/10.4102/hts.v69i2.1296

Dames, C., 2015, 'Glory', Photo recording of the original painting, February 2, 2017, Wilderness, George.

Dames, C., 2019, 'Holy generation', Photo recording of the original painting, March 12, 2020, Heather Park, George.

De Haas, H., 2020, Cape friends of calligraphy, viewed 30 March 2020, from https://sites.google.com/site/capefriendsofcalligraphy/home/4d-marchworkshop-uncial.

De Villiers, P.G.R., 2016, 'Re-enchanted by beauty. On aesthetics and mysticism', HTS Teologiese Studies/Theological Studies 72(4), a3462. https://doi.org/10.4102/ hts.v72i4.3462

Fróis, J.P., 2011, 'Introductory note to "Contemporary psychology and art: Toward a debate", by Lev, S. Vygotsky', Journal of Aesthetic Education 45(1), 107-118. https://doi.org/10.5406/jaesteduc.45.1.0107

Guder, D.L., 2000, The continuing conversion of the church, Eerdmans, Grand Rapids, Michigan, MI.

Hoek, S., 2020, No more weeping widow, viewed 19 May 2020, from https://www. facebook.com/101181758062219/posts/163386905175037/.

Jika, T., Skiti, S. \& Gilili, C., 2020, 'Fear, ignorance stalks returnees: The cost of placing South African evacuees from Wuhan in quarantine in Limpopo will cost an estimated R6.7-million', Mail \& Guardian, 13-19 March, p. 3.

Jika, T. \& Gilili, C., 2020, 'South Africa to fly citizens out of Wuhan: South Africa is to evacuate 132 people as the severe acute respiratory syndrome coronavirus 2 spreads', Mail \& Guardian, 28 February-05 March, p. 4.

Keifert, P., 2006, We are here now, a new missional era: A missional journey of spiritual discovery, Allelon, Eagle, Idaho, ID.

Kolwapi, L., 2020, 'Admit to white privilege before you 'join' black struggle', Sunday Times, 07 June, p. 14

Lam, J.E., 2015, 'Reading the Songs of Songs through a spiritual direction lens', HTS Teologiese Studies/Theological Studies 71(1), 9p. https://doi.org/10.4102/hts. v71i1.2959

Loff, C., 1993, 'Kol Bosch sluit finaal sy deur', Die Ligdraer, 13 September 13, p. 9.

Louw, D.J., 2005, Mechanics of the human soul: About maturity and life skills, Sun Press, Stellenbosch.

Louw, D.J., 2011, 'Ta splanchna: A theopaschitic approach to a hermeneutics of God's praxis. From zombie categories to passion categories in theory formation for a practical theology of the intestines', HTS Teologiese Studies/Theological Studies $67(3), 1-13$, viewed 08 May 2020, from https://doi.org/10.4102/hts.v67i3.1087

Louw, D.J., 2016, 'Preaching as art (imaging the unseen) and art as homiletics (verbalising the unseen): Towards the aesthetics of iconic thinking and poetic communication in homiletics', HTS Teologiese Studies/ Theological Studies 72(2), a3826. https://doi.org/10.4102/hts.v72i2.3826 
McCauley, R., 2020, 'Violence against women is the problem of every man in South Africa: Eradicate the scourge by socialising our children, examining our beliefs', Sunday Times, 28 June, p. 20.

McCormack, K., 2020, 'If this time', viewed 24 May 2020, from https://www.youtube. com/watch? $v=F I N e X A-f R Z E$

Meylahn, J.-A., 2020, 'Being human in the time of Covid-19', HTS Teologiese Studies/ Theological Studies 76(1), a6029, viewed 05 May 2020, from https://doi. org/10.4102/hts.v76i1.6029.

Noble, A., 2020a, 'Jesus light of the world. Wilderness Christian Fellowship's Sunday morning', viewed 19 April 2020, from service https://youtu.be/ HaOIbV7PGM4.

Noble, A., 2020b, 'Images for Anthony Noble artist', viewed 18 May 2020, from https://images.app.goo.gl/zZ8iAeTZ2yK5WV5v5.

Noble, A., 2012, 'God's word in art: For I know the plans I have for you, plans to prosper you, to give you hope and a future...', With ENN, endtimesnetwork. com, viewed 18 May 2020, from https://tinyurl.com/y8h66jlj 15/5/2020.

Noble, A., 2018, "Guest "Artistic" presentation by Mr Anthony Noble, a teacher at Dellville Primary School', George at the 2018 AGM and Congress Presentation Careers exhibition and information association annual general meeting and congress, 16-18 October 2019, East London, viewed 18 May 2020, from https:// tinyurl.com/y9e9qznt.

Nouwen, H.J.M., 1981, The way of the heart: Desert spirituality and contemporary ministry, Darton, Longman and Todd, London.
Oliveira, D., 2020, Templo dos anjos (Clamor pelo Brasil BR neste Domingo no Templo dos Anjos ...), viewed 20 May 2020, from https://www.youtube.com/ watch?v=WB1zp4MzHXU.

Ricoeur, P., 1991, On Paul Ricoeur: Narrative and Interpretation, Edited by David Wood, Routledge, London.

Ridderbos, H., 1962, The coming of the Kingdom, Transl. H. De Jongste, ed. R.O. Zorn, The Presbyterian and Reformed Publishing Company, Philadelphia, PA.

Saferspaces, 2020, Gender-based violence in South Africa, viewed 25 June 2020, from https://www.saferspaces.org.za/understand/entry/gender-based-violence-insouth-africa.

Simon, P. \& Garfunkel, A., 2009, The sound of silence, Madison Square Garden, New York, NY, 29 and 30 October 2009, viewed 19 May 2020, from https://www. youtube.com/watch?v=L-JQ1q-13Ek.

Sokol, R., 2020, Thank you coronavirus, viewed 25 March 2020, from https://tinyurl com/y7q99qyz.

Vygotsky, L.S., 2011, 'Contemporary psychology and art: Toward a debate [Sovremennaia psichologia e iskusstvo. V poriadke obsuzhdenia]', Journal of Aesthetic Education 45(1), 107-118. https://doi.org/10.1353/jae.2011.0002

Urban, J., 2020, 'Atheist doctor in Italy turns to God while on duty fighting against coronavirus', Produced 27 March 2020, viewed 05 April 2020, from https:www. faithpot.com.

World Health Organisation, 2020, viewed 25 June 2020, from www.who.int.

2Pac Pipe, 2020, F-Virus Prince Ea [Subtítulado], viewed 03 April 2020, from https://www.youtube.com/watch?v=yw1YSDmgTFI. 